\title{
Introduction: towards a cross-disciplinary history of the global in the humanities and the social sciences $\dagger$
}

\author{
Neus Rotger, Diana Roig-Sanz and Marta Puxan-Oliva \\ Department of Arts and Humanities and IN3, Universitat Oberta de Catalunya, Avinguda Tibidabo 39-43, 08035, Barcelona, \\ Spain \\ E-mails: nrotgerc@uoc.edu; dsanzr@uoc.edu; mpuxano@uoc.edu
}

The interdisciplinary analysis of historical and contemporary global issues with increasingly productive flows of theories, concepts, methods, and practices is a principal goal in global studies. However, within the humanities and the social sciences, the idea of the 'global' is often restrained by disciplinary boundaries, with scant dialogue and transference between them. The present special issue addresses this fundamental gap by historicizing the notion of the 'global' in an interdisciplinary dialogue, with approaches from history, sociology, anthropology, literary studies, art history, and media and communication studies. ${ }^{1}$ Our objective is to gain greater insights on the global approach from several disciplines and to let their borrowings and contributions emerge.

The issue responds to a double demand: on the one hand, it undertakes the task of historicizing global perspectives for several disciplines in the humanities and the social sciences, providing a thorough intervention in the state of the art; on the other hand, it juxtaposes six disciplines to encourage fruitful cross-pollination and to address problems and challenges within a global dimension. The issue has four specific goals: first, to illuminate shared or divergent genealogies and chronologies, showing which theories, methodologies, and approaches to the global have been more productive and can further new paths of cross-disciplinary inquiry; second, to unearth unforeseen relations between disciplines, helping to better acknowledge their borrowings and connections; third, to show contextual and institutional disciplinary changes at a transnational scale, as well as the ideological agreements and discrepancies that often accompany these; and, fourth, to provide a pool of concepts and practices that will enrich the range of possibilities for the advancement of global perspectives in each discipline.

\section{Historicizing the global approach}

As an epistemological premise, rather than as a complementary view, we understand 'global' as a research approach that examines cultural, social, political, or artistic phenomena on a larger

\footnotetext{
†This special issue began to take shape in the seminar 'Global perspectives in the humanities and social sciences', which the Global Literary Studies Research Group (GlobaLS) organized in Barcelona in 2017. We thank the Department of Arts and Humanities at the Universitat Oberta de Catalunya (UOC), and the MapModern project (Spanish Ministerio de Economía, Industria y Competitividad), for their financial support. We also wish to thank the keynote speakers (Béatrice Joyeux-Prunel, Jernej Habjan, Katja Naumann, and Peter Wagner) and seminar participants for their lively and productive discussions, which helped us reflect on the history of the global through different disciplinary perspectives.

${ }^{1}$ See, respectively, in this issue, Katja Naumann, 'Long-term and decentred trajectories of doing history from a global perspective: institutionalization, postcolonial critique, and empiricist approaches before and after the 1970s'; Romain Lecler, 'What makes globalization really new? Sociological views on our current globalization'; Gustavo Lins Ribeiro, 'The global/ local tension in the history of anthropology'; Jernej Habjan, 'The global process of thinking global literature: from Marx's Weltliteratur to Sarkozy's littérature-monde'; Béatrice Joyeux-Prunel, 'Art history and the global: deconstructing the latest canonical narrative'; and Ralph Schroeder, 'Historicizing media, globalizing media research: infrastructures, publics, and everyday life'.
}

(c) Cambridge University Press 2019. 
scale than the national, from a multidirectional perspective. The global approach pays attention to units of analysis that go beyond national frameworks, in order to analyse cross-border phenomena that result in thus-far overlooked movements and connectivities. This global approach enables us to interrogate cross-border histories and disciplines within specific national academic traditions and provides a framework to relate a wide range of theories and methods, as well as new ways of data collection and interpretation. However, our global approach does not attempt to engage in an encyclopaedic approach, nor does it represent a mere extension of national histories. ${ }^{2}$ Indeed, there is a consensus that global history (no matter what area: art history, economic history, political history, literary history, and so forth) is not the history of artworks, economies, political movements, or literatures everywhere. Instead, global history (in a broad sense) is concerned with interactions, processes of exchange, and cultural differences in various locations, but also at different points in time. People, goods, and ideas have always travelled far across linguistic and geographical borders. In current scholarship, a global approach could allow for the creation of a global history that would yield more complete research on local and national histories. ${ }^{3}$

New approaches to global history studies (from the 1990s onwards) ${ }^{4}$ have explored transnational connections and networks and the social capital that they represent, or how transnational encounters are shaped by asymmetrical power relations, as with entangled history. ${ }^{5}$ Especially relevant to the study of go-betweens, entangled history examines movements, intersections (and disentanglements), and their resulting effects. Since global history (in a broad sense) is inherently associated with flows of texts, ideas, artworks, concepts, practices, and people, a focus on cultural mediators highlights ties, rather than viewing cultures as distinct entities, and helps overcome the simplistic idea of a giving and a receiving culture. ${ }^{6}$ A global approach would aim to incorporate subaltern voices and reveal unsuspected relations that have shaped major discourses, while considering key concepts such as connectedness, porosity, flexibility, and openness. ${ }^{7}$ It likewise examines discontinuities and reassesses assumed connections produced, for example, by the different reception of ideas in different contexts. ${ }^{8}$

Thus, attempts to expand the national framework have taken different forms and have adopted varying theoretical perspectives. The notion of 'cultural transfer', first coined in 1987, aimed to overcome the trap of an exclusively national framework, but focused for many years on exchanges within Europe and between two national cultures, thus reproducing ideas of nation-states and binary exchanges. ${ }^{9}$ In a similar vein, postcolonial and subaltern studies, the so-called spatial turn, and world literature also address the challenge of overcoming the

\footnotetext{
${ }^{2}$ Andreas Eckert, 'Area studies and the writing of non-European history in Europe', in Matthias Middell and Lluís Roura, eds., Transnational challenges to national history writing, Basingstoke: Palgrave, 2013, pp. 140-63.

${ }^{3}$ Donald Sassoon, The culture of the Europeans, London: Harper Press, 2006; Akira Iriye and Pierre-Yves Saunier, eds., Palgrave dictionary of transnational history, Basingstoke: Palgrave, 2009; Christopher Bayly et al., 'AHR conversation: on transnational history', American Historical Review, 3, 5, 2006, pp. 1441-64.

${ }^{4}$ Arjun Appadurai, Modernity at large: cultural dimensions of globalization, Minneapolis, MN: University of Minnesota Press, 1996; Matthias Middell and Katja Naumann, 'Global history and the spatial turn: from the impact of area studies to the study of critical junctures of globalization', Journal of Global History, 5, 1, 2010, pp. 149-70.

${ }^{5}$ Michel Werner and Bénedicte Zimmermann, De la comparaison à l'histoire croisée, Paris: Seuil, 2004.

${ }^{6}$ Diana Roig-Sanz and Reine Meylaerts, eds., Literary translation and cultural mediators in 'peripheral' cultures: customs officers or smugglers, Basingstoke: Palgrave Macmillan, 2018.

${ }^{7}$ Geoffrey Gunn, History without borders: the making of an Asian world region, 1000-1800, Hong Kong: Hong Kong University Press, 2011.

${ }^{8}$ Nora Catelli, 'Asymmetry: specters of comparativism in the circulation of theory', in Marta Puxan-Oliva and Annalisa Mirizio, eds., 'Rethinking world literature studies in Latin American and Spanish contexts', special issue of Journal of World Literature, 2, 1, 2017, pp. 11-26.

${ }^{9}$ Michel Espagne and Michael Werner, 'La construction d'une référence culturelle allemande en France: genèse et histoire (1750-1914)', Annales, 4, 1987, pp. 969-92; Michel Espagne, 'La notion de transfert culturel', Revue Sciences/Lettres, 1, 2013, http://journals.openedition.org/rsl/219 (consulted 28 June 2019).
} 
nation-state limitations by pointing to the idea of a more diverse and interconnected world. ${ }^{10}$ Scholarship on social networks, world systems, and world society theories has similarly been informed by different perspectives. ${ }^{11}$ However, global approaches often reduce intercultural entanglements to networks involving Europe or the Western world, and the mainstream national focus of many disciplines does not sufficiently acknowledge the role of European peripheral fields, nor the complexities of non-European ones, in social, economic, political, and cultural processes affecting a wide range of places simultaneously. The multiple regional connections are still marginalized, and more source-based and empirical work is greatly needed.

Within this framework, one of the greatest challenges for decentred and non-Eurocentric global histories is to engage in larger accounts of historical processes (both geographically and temporally) and focus empirically on regional and urban differences. ${ }^{12}$ Undoubtedly, globalization debates have stressed the need to deconstruct nationalism and to portray knowledge production as a shared history where 'local happenings are shaped by events occurring miles away and vice versa'. ${ }^{13}$ Likewise, the conception of space beyond national frontiers has propelled a perspective of global space as flexible, interconnected, multidirectional, and in constant flow, which forces us to rethink in global terms the elements of comparison, their relationship, and the scale in which they move. On this note, the so-called 'spatial turn', mostly nurtured by critical geography, ecocriticism, and political philosophy, placed space and movement at the core of many current and internationally shared problems and stimulated a revision of ideas about their intertwined complexity.

\section{Towards a cross-disciplinary history}

The global turn is not confined to a single field but is an all-encompassing reorientation in the study of culture and society that cuts across disciplines. A widespread view in global studies today is that, in order to be able to think cross-culturally, scholars need to start working cross-disciplinarily. Concerns about the fragmentation of specialized disciplinary research are common and recurring among humanists and social scientists, who have increasingly expressed the need to overcome the segmentation of knowledge production through interdisciplinary exchange. ${ }^{14}$ Significant in this regard is the proliferation of journals that undertake the global under the premise of interdisciplinarity. For the editors of Global Networks, for instance, 'the study and analysis of new global networks

\footnotetext{
${ }^{10}$ For postcolonial and subaltern studies, see Edward Said, Reflections on exile and other literary and cultural essays, London: Granta Books, 2001; Hommi Bhabba, The location of culture, Abingdon: Routledge, 2004; Dipesh Chakrabarthy, Provincializing Europe, Princeton, NJ: Princeton University Press, 2000 (new edition 2007); Gayatri Spivak, Can the subaltern speak?, New York: Columbia University Press, 2010. For the spatial turn, see Doreen Massey, For space, London: SAGE, 2005; David Harvey, Rebel cities: from the right to the city to the urban revolution, London: Verso, 2012; Edward S. Casey, Getting back into place: toward a renewed understanding of the place-world, Indianapolis, IN: Indiana University Press, 1993, 2009; Edward Soja, Thirdspace: journeys to Los Angeles and other real-and-imagined places, Oxford: Basil Blackwell, 1996; Lawrence Buell, The future of environmental criticism: environmental crisis and literary imagination, London: Blackwell Publishing, 2005. For world literature, see Pascale Casanova, La république mondiale des lettres, Paris: Seuil, 1999; David Damrosch, What is world literature?, Princeton, NJ: Princeton University Press, 2003; Franco Moretti, 'Conjectures of world literature,' New Left Review, 1, 2000, pp. 55-67; Alexander Beecroft, An ecology of world literature, New York: Verso, 2015; Mariano Siskind, Cosmopolitan desires: global modernity and world literature in Latin America, Evanston, IL: Northwestern University Press, 2014.

${ }^{11}$ Immanuel Wallerstein, The capitalist world economy, Cambridge: Cambridge University Press, 1979; Pierre Bourdieu, La distinction, Paris: Éditions de Minuit, 1979; Bruno Latour, Science in action, Cambridge, MA: Harvard University Press, 1987; Niklas Luhmann, Social systems, Stanford, CA: Stanford University Press, 1995.

${ }^{12}$ Paul Jay, Global matters: the transnational turn in literary studies, Ithaca, NY: Cornell University Press, 2011; Vinay Lal, 'Provincializing the West: world history from the perspective of Indian history', in Benedikt Stuchtey and Eckhardt Fuchs, eds., Writing world history 1800-2000, Oxford: Oxford University Press, 2003, pp. 91-133; Boaventura Sousa Santos, 'Beyond abyssal thinking: from global lines to ecologies of knowledges', Review (Fernand Braudel Centre), 30, 1, 2007, pp. 45-89; Eric Hayot, On literary worlds, New York: Oxford University Press, 2012.

${ }^{13}$ Anthony Giddens, The consequences of modernity, Stanford, CA: Stanford University Press, 1990, p. 64.

${ }^{14}$ Richard Drayton and David Motadel, 'Discussion: the futures of global history', Journal of Global History, 13, 2018, pp. 1-21.
} 
encourages an erasing, or at least redrawing, of traditional disciplinary boundaries'. ${ }^{15}$ To Barry K. Gills, founder of Globalizations, the move towards the global requires the journal to be 'as open as possible' and to move beyond the traditional social sciences and humanities to include contributions from the natural, environmental, medical, and public health sciences as well. ${ }^{16}$ Journals like this one also hope to be 'a forum for interdisciplinary encounters'; ${ }^{17}$ and the recently created History of Humanities claims to move into a new field of study, on the basis of both the global approach and the cross-fertilization between disciplines. ${ }^{18}$

Current debates on interdisciplinarity as a form of knowledge organization often involve distinctions (between multi-, inter-, and transdisciplinary research) and different methodological approaches (instrumental or epistemological), depending on the focus and orientation of the research (empirical or theoretical). ${ }^{19}$ Implicit in these debates is the assumption that varying degrees of collaboration go hand in hand with the success of the research, celebrating integration and convergence between disciplines over collaborative work in parallel or in sequence, regardless of the nature and objectives of the research.

In contrast to this, a rich body of scholarship - from sociology to philosophy of science and health research - has begun to question the belief that collaboration across traditional disciplinary boundaries necessarily results in more effective research and teaching. ${ }^{20}$ Indeed, cross-disciplinary exchanges can be successful even if they neither integrate nor transcend any disciplinary borders. To historicize the circulation and transfer of knowledge, practices, and tools between and across disciplines gives us highly valuable information about shared problems and premises, such as that of the global approach. It is only fair that this collaborative effort to historicize the global in individual disciplines and across their boundaries acknowledge the disciplinary diversity of cultural backgrounds, scholarly environments, and institutional practices.

By collecting studies on the history of the global from different disciplines in the humanities and the social sciences, we propose to open a space for comparison in order to explore and historicize continuities and discontinuities between disciplines and unearth some 'shared territories' and 'trading zones' that bring them closer together. ${ }^{21}$ To date, the global turn has yet to be historicized from an interdisciplinary perspective. Within the humanities and social sciences, there is a growing interest in historicizing the global, even though their perspectives tend to be uni-disciplinary. ${ }^{22}$

\footnotetext{
${ }^{15}$ Alisdair Rogers, Robin Cohen, and Steven Vertovec, 'Editorial statement', Global Networks, 1, 1, 2001, p. v.

${ }^{16}$ Barry K. Gills, 'The turning of the tide', Globalizations, 1, 1, 2004, p. 2.

${ }^{17}$ William Gervase Clarence-Smith, Kenneth Pomeranz, and Peer Vries, 'Editorial', Journal of Global History, 1, 1, 2006, p. 2.

${ }^{18}$ Rens Bod, Julia Kursell, Jaap Maat, and Thijs Weststeijn, 'A new field: history of humanities', History of Humanities, 1, 1, 2016, pp. 1-8; and The Editors, 'Going global', History of Humanities, 1, 2, 2016, pp. 211-12.

${ }^{19}$ Julie Thompson Klein, Interdisciplinarity: history, theory, and practice, Detroit, MI: Wayne State University Press, 1993; Bernard C. K. Choi and Anita W. P. Pak, 'Multidisciplinarity, interdisciplinarity and transdisciplinarity in health research, services, education and policy', Clinical and Investigative Medicine, 29, 6, 2006, pp. 351-64.

${ }^{20} \mathrm{On}$ the case against interdisciplinarity, see Jerry A. Jacobs, In defense of disciplines: interdisciplinarity and specialization in the research university, Chicago, IL: University of Chicago Press, 2014.

${ }^{21}$ Julie Thompson Klein, Humanities, culture, and interdisciplinarity: the changing American academy, Albany, NY: State University of New York Press, 2005, pp. 39, 79.

${ }^{22}$ For historiography, see Daniel Woolf, A global history of history, Cambridge: Cambridge University Press, 2011; Daniel Woolf, gen. ed., The Oxford history of historical writing, 5 vols., Oxford: Oxford University Press, 2011-12; Georg G. Iggers, Q. Edward Wang, and Supriya Mukherjee, A global history of modern historiography, London: Routledge, 2013; Sven Beckert and Dominic Sachsenmaier, eds., Global history, globally: research and practice around the world, London: Bloomsbury, 2018. For philology, see James Turner, Philology: the forgotten origins of the modern humanities, Princeton, NJ: Princeton University Press, 2014; Sheldon Pollock, Benjamin A. Elman, and Ku-ming Kevin Chang, eds., World philology, Cambridge, MA: Harvard University Press, 2015. For art history, see Thomas DaCosta Kaufmann, Catherine Dossin, and Béatrice Joyeux-Prunel, eds., Circulations in the global history of art, Farnham and Burlington, VT: Ashgate, 2015. For sociology and international relations, see Julian Go and George Lawson, eds., Global historical sociology, Cambridge: Cambridge University Press, 2017. For a crossdisciplinary history of the humanities, see Rens Bod, A new history of the humanities: the search for principles and patterns from antiquity to the present, Oxford: Oxford University Press, 2013, and the new journal History of Humanities published by the University of Chicago Press since 2016.
} 
We believe that our aim is more modest, for we are not attempting to historicize globalization as a whole, but instead the global turn in scholarship. However, we also see our aim as groundbreaking, because of the cross-disciplinary approach. ${ }^{23}$ The six disciplines covered in this special issue are significant because of their strong national historiographical traditions (history, literary studies, and art history); their great impact on other disciplines (history, sociology, and anthropology); and the global idiosyncrasy of their object of study (anthropology, and media and communication studies).

We argue that the value of this historical, cross-disciplinary approach to the global lies in identifying and contextualizing continuities, discontinuities, and shared problems and challenges, like those concerning terminology, scale, and periodization; examining the methods deployed; evaluating the impact of technological changes; reflecting on the ethics and politics of the global within different academic environments; and assessing some of the institutionalization processes that have been, and still are, shaping global scholarly production. In the rest of this introduction, we set the six articles in dialogue in order to address these issues, as we believe the history of the global approach can benefit from cross-disciplinary reflection.

\section{Continuities, discontinuities, and shared territories}

One of the challenges that most clearly cuts across disciplines is that of terminology. The debate over the distinction between 'world' and 'global' initiatives has yielded much confusion within the humanities and the social sciences as a whole, and no consensus has emerged, despite some attempts to define the two approaches, or even to posit them as opposites. ${ }^{24}$ The specificity and value of the term 'global' also competes with a large variety of other tags, each one having different connotations and acceptance rates among scholars from various disciplines. For example, discussing history, Naumann adds to the more common use of 'world', 'international', or 'transnational' by inserting related terms such as 'world-systems', 'connected', 'entangled', 'area', 'transcultural', 'transregional', and 'big' history, emphasizing how all these terms involve a critique of Eurocentric perspectives and methodological nationalism. In disciplines like literary and cultural studies or art history, we should also note the heated controversies around the terms 'world', 'global', and 'planetary', in which users of the words 'world' and 'planet' try to distance themselves from the critique levelled at the 'global', emphasizing a cosmopolitan and ecocritical view. ${ }^{25}$

The debate over terminology has also led to the recovery of old metaphors and the creation of new concepts, some of them having the ability, or the potential, to travel across disciplinary borders. Seeking to privilege ideas of connectivity, openness, and movement above those of isolation, influence, and diffusionism, scholars in various disciplines tend to privilege, with varying degrees of precision and reflexivity, metaphors such as circulation ('currently one of the most widely employed words in the language of global history'), flow, and network. ${ }^{26}$

In close relation to these metaphors and their methodological connotations, it is important to note the creation of cross-disciplinary neologisms such as 'transmigrancy', coined in the 1990s to define migrants whose identities were shaped by multiple and constant cross-border

\footnotetext{
${ }^{23}$ For a brief genealogy of the role of the humanities and social sciences in interdisciplinary studies and funding programmes, see David Budtz Pedersen, 'Integrating social sciences and humanities in interdisciplinary research', Palgrave Communications, 2, 2016; Said Amir Arjomand, 'The rise of interdisciplinary studies in social sciences and humanities and the challenge of comparative sociology', European Journal of Social Theory, 20, 2, 2017, pp. 292-306.

${ }^{24}$ Martin Kern 'Ends and beginnings of world literature', Poetica, 49, 2017/18, pp. 1-31.

${ }^{25}$ Christian Moraru, “World," "globe," "planet”: comparative literature, planetary studies, and cultural debt after the global turn', in American Comparative Literature Association, 'The 2014-2015 report on the state of the discipline of comparative literature', Paradigms, https://stateofthediscipline.acla.org/entry/“world"-"globe"-"planet"-comparative-literature-planetarystudies-and-cultural-debt-after (consulted 12 July 2019).

${ }^{26}$ Stefanie Gänger, 'Circulation: reflections on circularity, entity, and liquidity in the language of global history', Journal of Global History, 12, 2017, p. 303; Stuart Alexander Rockefeller, 'Flow', Current Anthropology, 52, 4, 2011, pp. 557-8.
} 
interconnections; 'glocalization', coined around the same time by Roland Robertson to stress the simultaneity of global and local trends in current social, political, and economic life; ${ }^{27}$ or, more recently, 'bibliomigrancy', to refer to the physical and virtual migration of books from one part of the world to another. ${ }^{28}$ Whereas these terms clearly relate and contribute to a liquid conceptualization of globalization, other terms stress isolation and non-circulation, such as 'untranslatability', coined by Emily Apter for literature (see Habjan), or communication, such as 'infrastructures', denoting large technological systems that work across borders (see Schroeder).

Another shared challenge in all disciplines taking a global approach is scale. Scale is a problem in that a global approach tries to take an object of study that is detectable beyond geographies drawn by local, national, or regional boundaries, in order to assess it from a global perspective. Since our understanding of the world changed with the advent of globalization and what Harvey calls a time-space compression or 'shrinking of the world', the study of global problems such as migration movements, drug trafficking, and financial flows more clearly involves the methodological difficulty of handling scale. ${ }^{29}$ This problem is present in at least two aspects. On the one hand, research demands specificity, while a global approach risks generalization, lack of particular knowledge, and ideological bias produced by a single place of enunciation. In this context, scholars have asked how to measure global phenomena through the study of historical contexts and conjunctures that are not fully representative of or easily translatable to global problems. On the other hand, research risks being understood as producing exhaustive or encyclopaedic knowledge.

Ribeiro shows that, since the origins of the discipline, anthropologists have addressed scale in the form of global interest in human beings and their cultural patterns, as well as local empirical work. Anthropologists have mostly developed ethnographic methods that combine local research with global approaches, forces of heterogeneity and homogeneity, ultimately embracing the 'range of scales' (jeu d'échelles) that the global approach offers today. As Ribeiro notes, anthropological methods, such as 'diffusionism', have helped other disciplines deal with a global scale. A common way of addressing the challenge of scale has been to develop multi-sited research that looks at the same problem in multiple locations. However, as Naumann notes for history, Schroeder for media and communication, and Habjan for literature, the ambition of using a global scale has at times produced unbalanced attention towards certain regions, or even towards full continents or subcontinents, such as Africa, Asia, and South America, in attempts to compensate for earlier Anglo-European disciplinary traditions.

Regarding periodization, the global turn, as with other cultural turns, developed at different speeds, depending on geographies and cultural contexts. There is thus no single periodization or point of origin, but rather multi-temporalities, varying durations, and different dynamics in theoretical and scholarly change. Interestingly enough, however, there seems to be a general agreement that the global approach is at once very old and very young - an ancient and yet young and innovative mode of history writing, to use Osterhammel's expression. ${ }^{30}$ Thus, whereas world history is as old as history itself, the conception and practice of a multipolar, interactive, and transcultural history can only be dated back to the 1960s and, more securely, to the 1980s and 1990s (see Naumann). For the field of anthropology, Ribeiro situates the foundation of the global approach in the nineteenth-century beginnings of the discipline, when evolutionism and diffusionism supplied anthropologists with 'global' visions. It was also in the 1980s and 1990s that the first anthropological works on globalization appeared, such as Eric Wolfs 1982 Europe and the people without history. In a similar vein, Lecler establishes different 'waves of

\footnotetext{
${ }^{27}$ Roland Robertson, Globalization, London: Sage, 1992; Erik Swyngedouw, Glocalisations, Philadelphia, PA: Temple University Press, 2004. See also Lecler and Ribeiro in this issue.

${ }^{28} \mathrm{~B}$. Venkat Mani, Recoding world literature: libraries, print culture, and Germany's pact with books, New York: Fordham University Press, 2017.

${ }^{29}$ David Harvey, The condition of postmodernity, Oxford: Basil Blackwell, 1989; for a discussion of Harvey in anthropology, see Ribeiro in this issue.

${ }^{30}$ Jürgen Osterhammel, 'World history', in Axel Schneider and Daniel Woolf, eds., Oxford history of historical writing, vol. 5, Oxford: Oxford University Press, 2011, p. 93; see also Naumann in this issue.
} 
globalization', with the first one occurring in the middle of the nineteenth century, when Marx diagnosed the 'global' expansion of capitalism, while the latest wave again took place around the late 1980s and 1990s.

The question then, as Lecler argues for sociology, is 'What makes globalization really new?' He addresses the specificity of our globalized world through an analysis of six fundamental aspects of contemporary globalization. And with his analysis comes the realization, which is also valid for other disciplines, that the historical peaks in the debate about the global tend to coincide with those in modern global history. Schroeder for media and communication, and Habjan for literature, argue that global processes have an impact on succeeding waves of theorization, from the bourgeois revolution to the two world wars, the fall of the Berlin Wall, the fall of the Twin Towers, the rise of China, and, even more recently, the Brexit referendum and the Trump presidency. For art history, too, Joyeux-Prunel questions the canonical narrative that situates the new wave of the global in the 1980s with the so-called postcolonial turn among art historians, arguing instead that the global approach only emerged in the early 2000s, with the globalization of the art market playing a greater role than postcolonial theory.

Another major challenge in global approaches is methodology. Global practitioners have utilized and debated, among others, comparative, digital, and empirical methods. Comparative methods have been central to the global approach, partly because the latter emerged from comparative disciplinary practices (such as comparative literature and imperial history). These comparative methods have travelled across disciplines in different forms, using comparison and multisited analyses to posit world systems, entanglements, and intersections (noted in all the articles in this issue) in order to face the problem of how to deal with global issues happening in various contexts, where continuities and discontinuities might not be easy to grasp (see, for example, Schroeder). Comparative methods still struggle with traditional criticism regarding the number and relationships between comparative cases (many of which are still limited to bilateral exchanges) and the units deployed (including 'world' or 'planet', controversial Western units such as 'class', and nationally dependent units). Instead, research is pushing towards multidirectional, network-comparative methods and new units of analysis, such as oceans.

Digital methods, in turn, are being developed by a wide community of scholars from different disciplines who work with large-scale contexts. In literary studies, Franco Moretti has pioneered a quantitative and distant-reading approach, which has been followed by others (see Habjan for literature and Joyeux-Prunel for art history). ${ }^{31}$ However, big data approaches, data mining, and knowledge data discovery have not been sufficiently applied to reframe networks and reevaluate actors and their value. In that respect, macro- and micro-historical analyses, computational tools, and visual representations of relationships between people (network maps) and of quantitative data regarding the circulation of knowledge production, may address some of the above-mentioned challenges, such as scale or politics.

Sources employed for the application of empirical methods have countered the criticism levelled as to a lack of specific, qualitative analysis. In various modulations, methods such as global ethnography (which was born in anthropology but is also used in sociology: see Ribeiro and Lecler), source- and archive-based analysis (as in history or literature), and even micro-history have served to mark distinctions - for example from universal history methods (see Naumann) - and have been shown not to be incompatible with larger, global views.

With respect to technological changes, the basic claim of the information age and the network society was that information technology would reduce distances, and that this would certainly impact the spatial distribution of social phenomena. ${ }^{32}$ However, as Schroeder suggests, we still

\footnotetext{
${ }^{31}$ Matthew Jockers, Macroanalysis: digital methods and literary history, Springfield, IL: University of Illinois, 2013; Ted Underwood, 'A genealogy of distant reading', Digital Humanities Quarterly, 11, 2, 2017, http://www.digitalhumanities.org/ dhq/vol/11/2/000317/000317.html (consulted 12 July 2019).

${ }^{32}$ Manuel Castells, The rise of the network society, Malden, MA: Blackwell, 1996.
} 
need to measure the real benefits, losses, and reach of these technological changes and assess whether technology truly bridges the gap between the local and the global. Indeed, the information age has involved the circulation of large amounts of knowledge and data, but it has also brought insecurity and fake news.

Thus, by taking the idea of technological change as a social process that involves producers and consumers, who are boosted or limited by political, economical, and cultural constraints, global studies have focused on how communication and new technologies have affected urban development, how technological change helps build supposedly global citizens and promote smart cities that offer a high quality of life and sustainable environments, and how innovative technologies constitute key aspects of current globalization (see Lecler). In the field of media and communication studies, Schroeder questions the global expansion of the media and the internet by arguing that the main implications of far-reaching media lie in the extent to which they intervene in everyday life and are therefore geographically, linguistically, and nationally limited. The article traces this phenomenon historically, from the pre-modern period, when geographically extensive media networks only reached a small elite, through the modern print revolution, when the media's reach became both more extensive and more intensive, to the late nineteenth century, when media infrastructures penetrated everyday life more deeply. Emphasizing the need for a comparativehistorical perspective, Schroeder underlines the cases of India and China, so as to assess both the globalizing reach of media infrastructures within everyday life and its limits. Limitations also occur, for example, with new forms of censorship, as in the case of Venezuela, where digital rights are limited. To reach digital equality and sustainable development, we still need to work for digital freedom of expression, global internet access, open data, data rights, and privacy, as the World Wide Web Foundation and its policy director, Nnenna Nwakanma, advocate. In short, in accepting that the digital economy will only grow, we, as a society, should think in depth about what sort of technological change we can assume.

In regard to ideology, the emergence of theoretical frameworks such as Marxism, cultural studies, postcolonial and gender studies, and the new cosmopolitanisms has made global approaches highly conscious of ethical and political implications in scholarship. Among those, two major ones that cut across disciplines might be identified: first, the pressure to deprovincialize the critical perspective, which has been eminently Western, through the impact of postcolonial and decolonial approaches; and, second, the difficult relation between a global approach and globalization as a historical phenomenon. Most articles presented here deal with this double challenge.

In reference to the first challenge, Joyeux-Prunel especially addresses it, as she argues that art history did not start becoming global with the advent of postcolonial studies. Although art history had been concerned with non-Western artefacts and visual culture much earlier, through other movements such as primitivism or surrealism, the politics and ethics of these earlier global interests in art history were different. They later developed to counter nationalist and racist ideologies, which is what has partly brought art scholars to claim that the global turn actually took place later on, coinciding with a postcolonial approach in the 2000s. Naumann argues that history's earlier global interest distinguished itself from universal history research and teaching through cross-departmental programmes and graduate seminars, which were mostly promoted and created by non-Western scholars. In these Western-non-Western, and centre-periphery debates, new models are still emerging today. Proposals to decolonize thought, and to deal with the English monolingualism of the field, gender bias, and the question of who is entitled to speak, remain highly challenging.

In regards to the second aspect, Habjan, for literature, and Lecler, for sociology, demonstrate that the development of a global approach went hand in hand with the expansion of global capitalism, which would hint at why the global approach has received substantial criticism for favouring globalization and for privileging homogenization and global elites, instead of attending to discontinuity and diversity. As Ribeiro shows, this debate has been responded to with qualifications of 'globalization', such as the 'globalization of the poor', across disciplines. 
Finally, the institutional development of global studies as an academic field has proved to be diverse, according to geographical zones, academic traditions, and disciplines. Global studies is widely developed in central Europe and the English-speaking world, but it has not been successfully institutionalized yet in southern Europe, Africa, or Latin America, and is less prominent in art history (see Joyeux-Prunel). Academia has also promoted the institutionalization of global studies, which often oscillates between the study of the global as an object, as in most undergraduate programmes dealing with globalization processes and their effects on such issues as human rights or climate change, and the analysis of the global as an approach, as in research institutes and journals advancing new methods, concepts, and theories.

Thus, institutionalization builds on four main axes: first, teaching and education at the undergraduate, masters, and doctoral levels; second, research institutes such as the Global and European Studies Institute in Leipzig, or the Institute for World Literature at Harvard; third, journals, such as the Journal of Global History (established 2006; see Naumann), Globalizations (2004; see Lecler), Identities (1994; see Ribeiro), and the Journal of World Literature (2016; see Habjan); and, fourth, professional organizations, networks, associations, and conferences, such as the Global Studies Association, the World Anthropologies Network, the Asian Association of World Historians, and the World Congress of Art History.

Naumann traces the development of world and global history at the universities of Chicago and Harvard through teaching programmes and interdisciplinary cross-departmental work. These cases show that collaborative teaching programmes and intellectual and methodological shifts in graduate-level education as early as the 1960s led to the global approach through, for example, the creation of a $\mathrm{PhD}$ field of world history in the University of Chicago. In contrast, in art history, it was only in the 2000s that a clear institutionalization endeavour took place: after 2003, major European universities instituted courses and positions in world art studies and in transnational or global art history, and in 2010 the Centre Pompidou in Paris enhanced its 'Art and globalization' programme (see Joyeux-Prunel).

\section{Conclusion}

The shift from the local and the national to the global has produced new problems and challenges in various disciplines, which have been discussed in different ways by the authors in this issue. However, our authors share similar concerns, and we could potentially build some common timeframes, conceptual frameworks, and methodological tools. It is clear that collaboration between scholars from different regions is needed for a global approach, but this must be matched with a sustained and productive dialogue across disciplines. The opening up of cross-disciplinary spaces of research allows global scholars to exploit connections, pursue different modes of inquiry, and even move towards new subfields, such as medical humanities, environmental humanities, and migration studies.

Our presentation of six informed studies on the history of the global turn moves in this direction, which should be enriched with attention towards other key disciplines, such as economics, political science, law, and international relations. The present special issue both points to an effort to integrate these studies into an interdisciplinary history of the humanities and the social sciences and also proposes a broader, more holistic conversation on the global, which can help us push the field further towards deprovincialization.

As we have seen, the present issue has undertaken four main tasks. First, it historicizes and advances the discussion of well-known dichotomies, such as centre and periphery, global and local, North and South, and space and place. Second, it points to disciplinary debates, such as that of scale in anthropology, or the world/global terminological divide in literary studies, which can shed light on less-mature debates in other disciplines. Third, it contextualizes the institutional development of the global in scholarship, so that we can historicize the global approach in a more 
complete manner. Finally, it creates a new set of cross-disciplinary concepts, such as those of transmigrancy, bibliomigrancy, and glocalization. However, much more needs to be done to foster a truly global approach that integrates voices from different places and languages of enunciation, including non-English academic traditions, and that shows a deeper awareness of ideological biases such as gender and alterity. 